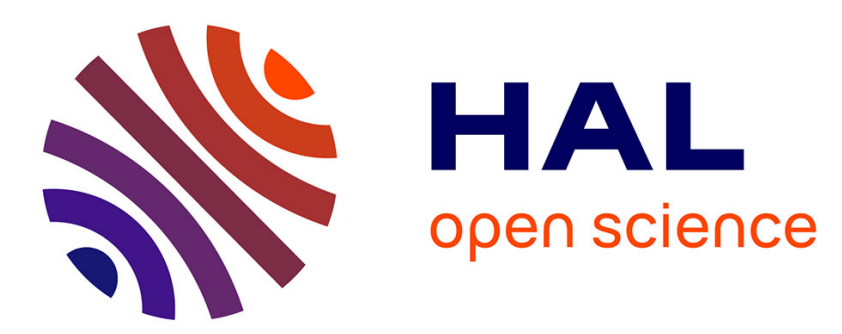

\title{
Caledonia Dreaming : commitment, literature and independence
}

\author{
Marie-Odile Pittin-Hedon
}

\section{To cite this version:}

Marie-Odile Pittin-Hedon. Caledonia Dreaming: commitment, literature and independence. Observatoire de la société britannique, 2016, 18, pp.129-145. 10.4000/osb.1831 . hal-01310269

\section{HAL Id: hal-01310269 \\ https://hal-amu.archives-ouvertes.fr/hal-01310269}

Submitted on 2 May 2016

HAL is a multi-disciplinary open access archive for the deposit and dissemination of scientific research documents, whether they are published or not. The documents may come from teaching and research institutions in France or abroad, or from public or private research centers.
L'archive ouverte pluridisciplinaire HAL, est destinée au dépôt et à la diffusion de documents scientifiques de niveau recherche, publiés ou non, émanant des établissements d'enseignement et de recherche français ou étrangers, des laboratoires publics ou privés. 


\title{
Caledonia Dreaming: commitment, literature and independence
}

\author{
Marie-Odile Pittin-Hedon
}

\section{Summary}

This paper examines the notion of commitment in literature in the contemporary context, and the connection between literature and nationalism in Scotland. It starts with the philosophical reflection on the goal of all art that Alan Riach and Alexander Moffat based their argument on in their book The Arts of Independence (2014), in order to underline the ways commitment is related to the history of cultural nationalism and to the representation of Scottish identity in contemporary literature, in places where this representation does appear. In order to do so, the paper tackles the necessity for artists to eschew what Eleanor Bell calls the postmodern predicament, in particular the dangers of an essentialist approach to Scottishness. It also examines the wider implications of the concept of cultural nationalism, in a context where inferiorism as well as banal nationalism are surfacing again. These recent developments have led artists and critics alike to try to devise new configurations for cultural nationalism, with the return of the idea of an "archipelagic" identity, or with a distinction being drawn between independence and inter-dependence for example. The part played by the artists in the independence debate, their commitment, has been precisely to promote a literature that looks at what, according to Riach and Moffat, is the essential goal and virtue of all art, to speak to and of our humanity.

Keywords: Independence referendum and literature, Alan Riach, Alexander Moffat, Iain MacWhirter, Ernest Gellner, Angus Calder, Eleanor Bell, banal Nationalism, essentialism, cultural nationalism, postmodern predicament, mongrel nation, Alan Bissett, Ewan Morrison, "Vote Britain”, inferiorism, Alasdair Gray, "Settlers and colonists", James Robertson, Irvine Welsh. 
"All arts work for independence". This is the opening sentence of The Arts of Independence, a book published in 2014 by Alexander Moffat, a painter and former chair of the School of Fine Art at the Glasgow School of Arts, and Alan Riach, a poet and professor of Scottish literature at Glasgow University. This book was written to assert that the cultural argument is a pre-eminent one for Scottish independence, which even trumps the political or the economic argument because of its permanence. It is an argument that has existed, in various forms, for many years, that of the primary importance of artists, for the vision that they can supply, a vision which can lead the country into the future. Marc Lambert, in a book edited by Gerry Hassan, Eddie Gibb and Lydia Howland in 2005, makes a very similar statement to Riach's and Moffat's starting point for their book:

Scenarios that will sustain us and move us forward in the future will be those scripted by our historians and writers. But ultimately I believe that fictions are stronger means than any science because their imaginative power is non linear and contains, in a Whitmanesque sense, multitudes. In short, we need to develop our imaginative and critical grasp of ourselves in order to have an informed opinion about what our future might be. ${ }^{1}$

The postulate therefore, and one of the notions surrounding the role of culture in the definition of the nation and the independence campaign, is that artists are almost by definition important actors in the Yes campaign. In his book Disunited Kingdom published after the referendum, journalist Iain MacWhirter makes an assessment that confirms Lambert's prediction, claiming that " $[\mathrm{t}]$ he referendum was the first time I can recall in Britain when artists and writers really were in the forefront of a political movement and not just ornaments to it." ${ }^{2}$ And indeed, many prominent artists and intellectuals have been very active advocates of an independent Scotland. One might think of the activism of organisations such as the Scottish Artists Union, blogs like the famous "Bella Caledonia", or the Saltire Society, both of which frequently publicize artists's views on independence, of the $f 1$ million donation

${ }^{1}$ Lambert, M., "The Age of Capitals: Edinburgh as Culture City", in G. Hassan, E. Gibb and L. Howland, (eds), Scotland 2020: Hopeful stories for a northern nation, London : Demos, 2005, p. 129.

${ }^{2}$ MacWhirter, I., Disunited Kingdom: How Westminster Won the Referendum but Lost Scotland, Glasgow: Cargo Publishing, 2014, p. 68. 
bequeathed by the poet Edwin Morgan to the Yes campaign (a donation in fact mirrored by the one of the same amount given by J.K.Rowling to the Better Together camp to considerable publicity), and of course, National Collective, which drew 1300 artists to back the Yes Campaign. Playwrights David Greig and Alan Bissett both campaigned very actively, Bissett as the leader of the Artists's Collective for independence. He also wrote a number of plays, ${ }^{3}$ one of them, The Pure, the Dead and the Brilliant, which was performed at the 2014 Edinburgh Fringe Festival, and which examines the possibility for an independent Scotland in a vibrant comedy, or in the words of Brian Ferguson in The Scotsman, "a rambunctious, energetic piece of agit-prop". "He has also been reading his poem 'Vote Britain' in many independence rallies and events throughout Scotland. This activism of the literary world is no surprise in a country where it has often been argued that in the 1980s and 1990s already, literature paved the way for devolution in the absence of political unity.

In 2013, Scott Hames collected essays on independence ${ }^{5}$ written by a variety of artists, among whom James Kelman, Janice Galloway, Alan Bissett, or Alasdair Gray. Hames's book, like The Arts of Independence, is an indication of the two interrelated factors which are very specific to the question of Scottish nationalism and Scottish independence: Scotland is a country where the political debate is intimately linked to the cultural issue, in other words, a country where cultural nationalism has a very important part to play in the definition of its own identity. As a result of this, artists, writers in particular, are expected to brush shoulders with politicians and pundits of all kinds in the independence conversation. It is in fact a right to dream the nation into existence, as is claimed in no uncertain terms by the poet Kathleen Jamie:

It seems to me that today's Independence "debate" is being handed down to us by career politicians so it immediately feels inauthentic. Full of inorganic political and economic impurities, you might say.

${ }^{3}$ See Bissett, A., Collected Plays 2009-2014, Glasgow: Freight Books, 2015.

${ }^{4}$ Brian Ferguson, The Scotsman, February 24, 2014. http://www.scotsman.com/what-son/theatre-comedy-dance/alan-bissett-scottish-independence-play-at-fringe-1$\underline{3317276}$, consulted February 2015. This description by Ferguson is in itself indicative of the kind of coverage the press gave to the yes campaign, as it crosses the line between militantism and agit propaganda with no real argument to justify this semantic choice. ${ }^{5}$ Hames, S., (ed.), Unstated: Writers on Scottish Independence, Edinburgh: Word Power books, 2012. 
There is no fun around it, that's for sure [...] Because we, the people, sense its falsity, we are not thinking and dreaming. Instead of dreaming a nation, we're reduced to fretting about "the economy".

\section{[....] Starting now, we need to imagine yet again the kind of Scotland we want. ${ }^{6}$}

But those expectations nevertheless beg a central question, the necessary distinction between the role of the artists working in Scotland and their writing. The pitfall is one of considering those writings as the index of their nationalist politics and therefore of reducing a work of art to a work of propaganda, which sometimes happens to Bissett's play as the quote above indicates. It is a dilemma which has been clearly if a little bluntly stated by another very important Scottish writer, whose picture and words are part of a permanent exhibition in the hall of the Holyrood Parliament, Janice Galloway, 'Who wants to write about nation all the bloody time?"?

So this paper will examine the notion of commitment in literature in the contemporary context, and the connection between literature and nationalism in Scotland, by starting with the philosophical premise that Riach and Moffat based their argument on, in order to show how it can be related to the history of cultural nationalism and to the representation of Scottish identity in contemporary literature, in places where this representation does appear. James Robertson, originally a writer of historical novels, in particular of a rewrite of James Hogg's Confessions, and of the state of the nation novel on the contemporary period $A$ nd the Land Lay Still, is often referred to as one of the most important writers of the decade. In the wake of the independence referendum, he wrote 365365 -word stories which were published first in the Hamish Hamilton online literary magazine, Fivedials, and then collected in a book. ${ }^{8}$ Commenting the project, Robertson insists on the link between history

${ }^{6}$ Kathleen J., in Hames, 2012, p. 116.

${ }^{7}$ Galloway, J., Edinburgh Review 100, 1999, p. 72.

8See Robertson, J., 365: stories, London: Penguin, 2014. 
and literature," writing that "We are made of stories, all of us. Stories make us. But what do we make of them?". 10

Robertson's point is to draw people's attention to their responsibility to "make" something of the stories - in the plural - they are made of, an argument that many an artist asserted in one form or another during the campaign. Taking this responsibility seriously, Riach and Moffat attempt in their book to capture the wider implications to the concept of cultural nationalism, a point that can be addressed by using Ernest Gellner's theory. For Gellner, cultural nationalism is "a political principle which maintains that similarity of culture is the basic social bond", and its slogan can be summed up as "one culture, one nation, one state". ${ }^{11}$ However for Riach and Moffat, who are starting from a philosophical reflection on the goal of all art, the emphasis is not primarily on similarity of culture, although they assert that artists present their nation's culture to the world, and that consequently "[n]o country can afford to have its cultural authority devolved to another country" (42), it is rather on the power of the arts to speak to, and of our humanity:

\section{Literature, painting, music, architecture - all the arts - are the most essential outward form in which we make distinct our own bumanity. (7)}

This fundamental capacity of the arts is therefore the possibility it gives us to see ourselves, a capacity which is the fundamental object of art, as we are reminded by Paul Valéry, when he writes about Leonardo $\mathrm{Da}$ Vinci that "une œuvre d'art devrait toujours nous apprendre que nous n'avions pas vu ce que nous voyons"12. Or by the German artist Paul Klee who, when endeavouring to define modern art, claims that "l'art ne reproduit pas le visible; il rend visible", 13 therefore countering Plato's original postulate that art is mimesis. For Valéry as for Klee, the

${ }^{9}$ For more on this, see Pittin-Hedon, M.-O., The Space of Fiction: Voices from Scotland in a Post-Devolution Age, Glasgow: ASLS, 2015, chapter 3 "James Robertson: The Contagion of History".

${ }^{10}$ From Robertson's conclusion to his presentation of the project. http://penguinblog.co.uk/2013/12/23/365-words-on-365/, December 23, 2013.

${ }^{11}$ Gellner, 1997, quoted in E. Bell and G. Miller, (eds)., Scotland in Theory: Reflections on Culture and Literature, Amsterdam and New York: Rodopi, 2004, p. 36.

${ }^{12}$ Valéry, P., CEuvres, éd. par J. Hytier, vol. I, Paris, Gallimard (coll. de la Pléiade), 1957, p. 1165.

${ }^{13}$ Klee, P., "Credo du créateur » in Théorie de l'Art moderne, Gonthier, Genève, 1969, p. 34. 
arts enable us to reach beyond appearances to the fundamental roots of our humanity, a line of argument which is taken up by Riach and Moffat, who claims that "[t]he arts all deepen and sharpen our sense and understanding of reality" (19). By adopting this inclusive definition of the purpose of art, they manage to stress its necessity in the national conversation about independence because it makes things visible, and takes us back to the fundamental question of what it means to be human, which according to Riach should be distinguished from "commercial, managerial, material humanity". ${ }^{14}$ One might add that art does that while steering clear of what Eleanor Bell describes as the postmodern predicament of the Scottish writer, which is that the writer in Scotland is required to capture an essence of Scottishness, which paves the way for an essentialist vision of identity. For Bell:

The postmodern predicament is [...] connected to a paradoxical situation whereby, on the one hand, there is a continual need by, for example, cultural nationalists, to view cultures and nations as "entities" in some coherent sense, yet, on the other, where belonging and organic association are now fundamentally in question. The postmodern predicament, as understood here, is therefore concerned with how to map the realities of present, and future, forms of nationhood in ways that take account of such theoretical development without lapsing into convenient forms of national essentialism. ${ }^{15}$

The danger of the essentialist approach is that it should hark back to an approach of identity centred around some sort of Celtic essence that is ultimately a self-defeating kind of cultural nationalism. As Carruthers, Goldie and Renfrew put it in 2004:

It has only been in recent times, as the need to disaggregate political from cultural nationalism has become apparent, that an end to the critical impasse has come into view, and we can discern more clearly the damage wrought by an over-determined, self-defeating essentialism fostered by Scottish criticism's overweening desire for cultural selfdetermination. It is significant in this respect that Scottish literature in the twentieth century has been much less inbibited by such considerations than Scottish criticism, much less beguiled by the apparent need to

\footnotetext{
${ }^{14}$ Alan Riach, book launch, http://www.youtube.com/watch?v=R3j4oSflHzM, consulted February 2014

${ }^{15}$ Bell, E., Questioning Scotland: Literature, Nationalism, Postmodernism, Basingstoke and New York: Palgrave Macmillan, 2004, p. 29.
} 

untangle a single-stranded Scottishness, and has found its "proper
ground" in beterogeneity and inter-dependence.

This essentialist temptation may have been that of critics, and mostly in the 1980s and 1990s, but it is a tendency which increased in the months before the referendum, with commentators, journalists in particular, urging artists to justify the actual existence of Scottish literature by naming its essential, unique feature, in a way that American, English or French writers are rarely summoned to do. The ultimatum usually takes the shape of the question, "is there such a thing as Scottish literature?" AL Kennedy's answer to that:

\section{Is there such a thing as English literature or Irish literature or American literature? You don't want to claim any literature for a country because it's international and has to do with the commonality of human experience, but Scotland exists, as a cultural entity, as an historical entity. I want somebody to be able to sit in a Scottish school and think, I can succeed, being myself from my country, using the language that I use, being the person that I am...} (Riach, 26)

In this refusal to endorse the postmodern predicament, Kennedy stresses the characteristic of Scottish literature of the last twenty years, which is its capacity to embrace its diversity. Angus Calder, in his 2002 book Scotlands of the Mind, which he intended as a reflection on Scottish identity and the Scottish nation not directly written as an argument in favour of independence - although he states in the introduction that he "would like an independent Scotland" - reflects on how diverse Scotland is, and how expressing a sense of Scottishness is made up of a plethora of cultural identities, taking up McIlvanney's idea of the "mongrel nation" as a "political tool"17. Kennedy makes a point that is connected to Calder's, emphasizing her wish for Scottish artists to be free from the necessity to speak with one voice, which is the underlying command contained in the "does it even exist?" question.

\footnotetext{
${ }^{16}$ Carruthers, G., Goldie, D., and Renfrew A., (eds), Beyond Scotland : New Contexts for Twentieth-Century Scottish Literature, Amsterdam and New York : Rodopi, 2004, p. 14.

17 "The concept of mongrelism also makes it easier to affirm diversity as, paradoxically, a basis for our unity." Calder, A., Scotlands of the Mind, Edinburgh: Luath Press, 2002, p. xiii.
} 
In that context, the situation today can be seen as a paradoxical one: in the run-up to the independence referendum of 2014, there seemed to be a return, if not to the essentialist vision of culture and identity, at least to a sharply antagonistic vision of the British/Scottish dilemma, in spite of all the efforts of the Yes campaign in particular to steer clear of that reductive opposition. Writers and participants in the independence conversation seem to have been led to revert to entrenched positions that were first expressed after the 1979 referendum when it appeared necessary for Scottish writers to define themselves and their nation in opposition to the English. One of the most famous examples of that in literature can be found in Irvine Welsh's Trainspotting, in a diatribe in which the protagonist Mark Renton dismisses the Scots for allowing their country to be colonized by the English:

\section{It's nae good blamin it oan the English fir colonizing us. Ah don't hate the English. They're just wankers. We are colonized by wankers. We can't even pick a decent, vibrant, healtby culture to be colonized by. ${ }^{18}$}

What is at stake in this quotation is Scotland's marginal status, which is violently asserted with the use of the rhetoric of imperialist domination. Thirty-five years later, when Caledonia is dreaming of independence, the antagonistic rhetoric reappears, as in Bissett's ironic poem "Vote Britain", which focuses on the ways in which Scotland has repeatedly been historically misrepresented, depicted as backward. This diatribe that sums up what one votes for when opting for the union, voices very ancient prejudices, as for instance in the following lines:

People of Scotland, vote with your heart.

Vote with your love for the Queen who nurtured you, cradle to grave,

Who protects you and cares, her most darling subjects, to whom you gave the glens she adores to roam freely through, the stags her children so dearly enjoy killing.

First into battle, loyal and true. The enemy's scared of you.

That's why we send you over the top with your och-aye-the-noo

Mactivish there's been a murrderrr jings! crivvens!

Deepfriedfuckinmarsbar wee wee dram of whisky hoots mon there's a

moose loose aboot this smackaddict

Vote, Jock. Vote, Sweaty Sock. Talk properly.

$[\ldots]$

${ }^{18}$ Welsh, I., Trainspotting, London: Mandarin, (1994), 1993, p. 78. 
Vote Labour. New Labour. Old Labour. Scottish Labour.

(Get back in line, Scottish Labour, HQ in Solibull will issue their commands shortly,

Just keep the vote coming in from up there thanks goodbye,

Subsidy junkie).

Vote for any argument you construct in your defence being "anti-

English".

Vote for Scots who make their career in Scotland

being "unambitious".

Vote for enjoying your own culture being so0000000 parochial. ${ }^{19}$

The use of such phrases as "subsidy junkies" and "smack addict" as well as he highly derogative "porridge mouth" further down in the poem harks back to the old dilemma of the Scottish/British identity. This takes us back to Craig Beveridge and William Turnbull's 1989 book, The Eclipse of Scottish Culture, which starts precisely on a review of the misrepresentation of the Scottish cultural tradition. In a manner that is vividly echoed over twenty-five years later in Bissett's poem, Beveridge and Turnbull begin with the notion that the socalled "Scottish inferiority complex" has often been established and perpetuated through binary oppositions which, they explain, have been integral to the historical representation of Scottishness. Here is a list of these oppositions, many of which are included in "Vote Britain":

$\begin{array}{ll}\text { Scotland } & \text { England } \\ \text { dark } & \text { enlightened } \\ \text { backward } & \text { advanced } \\ \text { fanatical } & \text { reasonable } \\ \text { violent } & \text { decent } \\ \text { barbaric } & \text { civilized } \\ \text { parocbial } & \text { cosmopolitan } \\ \text { uncouth } & \text { refined } \\ \text { intemperate } & \text { moderate } \\ \text { savage } & \text { mild } \\ \text { unruly } & \text { orderly } \\ \text { severe } & \text { kind } \\ \text { barsh } & \text { gentle }\end{array}$

${ }^{19}$ Bissett, A., "Vote Britain", http://alanbissett.com/2012/01/13/my-contribution-tothe-debate-on-scottish-independence/, consulted 20/2/15. 
Almost twenty years after The Eclipse of Scottish Culture, Eleanor Bell's Questioning Scotland examines the history and development of cultural nationalism in Scotland, and views Beveridge and Turnbull's contribution as an attempt to explain and correct this anomaly which consists in perpetuating inferiorist images of Scottish culture. ${ }^{21}$ What surfaces savagely in Bissett's poem is the need to put an end to what might remain of the inferiorist syndrome in Scottish life.

It is to be noted that Gray's contribution to Scott Hames' anthology on Independence, entitled "Settlers and colonists", which in a way was a definitive refusal of the inferiorist attitude, and a rejection of any manifestation of it that might still be present on the Scottish art scene created an uproar in Scotland. In this essay, Gray, who is also a painter, suggested that there were two kinds of senior arts administrators appointed in Scotland, those who come to Scotland to settle and try to understand the relations and the artistic traditions of the country, while others consider Scotland as a temporary appointment en route for better jobs, and treat Scotland as a region of the UK, therefore neglecting to assess and promote its art. This idea ties in with Moffat's own analysis of the management of such artistic institutions as Creative Scotland, with eloquent figures to back up his analysis. For example, Moffat indicates in the chapter entitled 'Scotland's self-suppression' that there hasn't been a Scottish director of the National Galleries in Edinbugh since 1949. In the field of literature, as we are reminded by blogger Chris Ward, Kelman was the first - and only - Scot to win the prestigious Booker Prize in 1994 in a period covering twenty years and producing forty-eight recipients. Gray's provocative way of presenting the ideas, especially his use of the terms "settlers" and "colonists" led to his essay being violently attacked and discarded as discriminatory, anti-English, and even downright racist, and few people spoke to defend him. In a 2015 book of criticism on Gray edited by Camille Manfredi, Scott Hames goes over the way the article was criticized even before it actually came out, with the result that most of the people

\footnotetext{
${ }^{20}$ Beveridge, C. and Turnbull, R., The Eclipse of Scottish Culture: Inferiorism and the Intellectuals, Edinburgh: Polygon, 1989, p. 7.

${ }^{21}$ The concept of inferiorism was first aired by Franz Fanon and refers to " the processes through which the native come to internalize the dominant culture of the colonizer at the expense of their own local, traditional cultures, which are undermined through forces of oppression.” Bell, Questioning Scotland, p. 71.
} 
(journalists, commentators, politicians) who criticized it did so on the basis of a few quoted comments separated from the context of their utterance, having not actually read the paper. Hames reports that in the month of December 2012, 119 articles were written in the UK press that mentioned Alasdair Gray, and that "a handful of articles in the most popular newspaper websites garnered 2500 comment alone.". 22 Among the rare people who defended Gray, was a Scotsman journalist specialized in financial and business matters, Bill Jamieson, who wrote in an editorial:

Mr Gray has set the cultural heather ablaze in recent days. In an essay he referred to English people appointed to top jobs north of the border as "settlers" and "colonists" who come here to advance their careers and move on. Progressive worthies in Scottish arts have recoiled in horror. "Shocking", "odious"; "ughy"; "bigoted", "narrow-minded nationalism" - even Apartheid in South Africa bas been invoked to describe Mr Gray's remarks. [...]

What he has done is to remind us, if rather more bluntly than some of his admirers would wish, that Scotland is more than a place, it is an idea.

Our writing, our language, our values, our history, our culture are not identical to those of the rest of the UK. There are many features that we share and enjoy in common. But Scotland is not England. To approach appointments in Scottish life and letters as if these were identical to and requiring no differentiation from appointments in the English regions is a misjudgment. $[\ldots]^{23}$

If anything, the furore that the essay created shows the part played by the media in the referendum campaign, in particular as it is widely acknowledged that the mass media were overwhelmingly backing the Better Together campaign in a way that might have tipped the balance in the final vote. It nevertheless also shows that making the decision to vote for or against an independent Scotland made it necessary to go back over territory that had been all but abandoned by artists since the late 1990s, as for example the fact that, as Jamieson reminds us when he states that "Scotland is not England", the basic characteristic of a nation is that it cannot be subsumed into another

\footnotetext{
${ }^{22}$ Hames, S., "The 'Settlers and Colonists' affair", in C. Manfredi, (ed.), Alasdair Gray, Ink for Worlds, Basingstoke and New York: Macmillan, 2014, p. 75.

${ }^{23}$ Jamieson, B., quoted in Riach and Moffat, p. 40.
} 
nation. Having to go over these questions again led many artists and intellectuals to bave to make the claim that they are not anti-English, but just not English.

In that context, Robertson's own contribution in 365: Stories can be seen not as an essentialist, or not even as an entrenched, them-vs-us position, but as a definitive refusal to be reduced to the peripheral status that being part of the union entails. He puts this blankly, though with an obvious sense of humour, in the story entitled "the news where you are" which, in MacWhirter's terms, "wickedly satirised the patronising, top-down attitude of metropolitan news bulletins". ${ }^{24}$ In this story, Robertson finally refuses the inferiorist attitude by simply dismissing it as ridiculous.

If one follows Jamieson's defence of Gray, and Robertson's amusing rhetorical exercise, the question that defines identity should not be, "where are you from", not even, in Gray's somewhat clumsy classification "are you a 'settler' or a 'colonist'?", with the assumption that it makes you who you are, in a definitive, unchangeable sort of way, but rather a much wider inquiry into what it is that makes people who they are. This is a question that artists, critics and historians alike have been tackling ever since the 1979 referendum, and arguably even before. In a way that recalls Calder's argument of mongrelism. Riach, at the launch of The Arts of Independence, insists on the fact that Scottish identity is not fossilized and entrenched, but what he calls, taking his cue - again - from Alasdair Gray, "archipelagic", by which he means an aggregate of diverse identities whose interconnections are constantly evolving. Carruthers, Goldie and Renfrew call this inter-dependence, to be preferred to independence, which might in some contexts sound too hegemonic.

But this has to be placed in the wider context of the reflection on the idea of the nation, with concerns linked to what Michael Billig, in his 1995 book Banal Nationalism, sees as the contemporary dissolution of the nation-state project in the late years of the $20^{\text {th }}$ century. What he calls banal nationalism refers to a situation in which the US promotes itself as the global ideal which prompts people to identify themselves to this "global" model. This can be related to another concept, that which the

${ }^{24} \mathrm{MacWhirter}, \mathrm{p} .66$. It has of course also been often noted that the story is a pastiche of Tom Leonard's own poem "Six O'Clock News". 
historian Benedict Anderson, in his book The Spectre of Comparison (1998) calls "late nationalism", referring to the ways in which nationalism has diversified and pluralised as a result of contemporary capitalism and the commodification of national identity inevitably linked to it. ${ }^{25}$ Ewan Morrison's work reflects this concern with the "global ideal" associated with American-style consumer capitalism, and its consequences on the definition of a nation's identity. In Tales from the Mall, he insists in its introduction, and in the various stories and anecdotes that it contains, that the consumerist drive symbolised by the shopping mall is in fact a void, a depressing space of nothingness. Many of the anecdotes and stories obsessively take up this motif, as for example the one entitled "King of Burger", which describes the life of a divorced father eating his meals at Burger King among several other "regulars" described as so many ghosts. In incident \# 15 Vasyl, the Ukrainian immigrant to Scotland, makes this clear when he asks his Western friends proudly showing off their shopping centre to him "where is the centre?"26. The narrator:

$V$ asyl always calls bimself Idiot! when he recounts this, but what he articulated was something many people from former communist countries have experienced and sometimes westerners feel periodically in time of estrangement: that there is something empty at the heart of consumerism.

[...] The centre is a space, not a place. A space between outlets (shops, food courts, entertainments) but also between people. (79)

Other stories make the same point, over and over: the shy men who attend a therapy session that is designed to help them relate to women and who practice by talking to women in shopping malls with the goal of getting their phone numbers, Betty, the old lady who goes to the shopping centre for company and to look at people walking by while drinking tea from her thermos flask, who gets evicted from the premises and abandoned at the back of the shopping mall by the dual carriageway, and many others. Morrison, in the introduction to this book insists that:

25 See Bell, Questioning Scotland, p. 54.

${ }^{26}$ Morrison, E., Tales from the Mall, Glasgow: Cargo, 2012, p. 78. 
The mallification of my country is an historic event, as important as the Jacobite Rebellion or the Highland Clearances.

[...] Tales from the Mall is an attempt to discover what has survived the levelling of consumerism and has potential resistance within my country as it becomes art of the globalised economy. (8-9)

Morrison's work, far from falling back upon an entrenched attitude that would consider the notion of Scottish identity in connection with/opposition to the English shows how late nationalism is in fact a levelling of all identities which leads to the endangering of the human. In that respect, it would justify Riach and Moffat's claim quoted at the beginning of this paper that all arts work for independence, crucially, in Morrison's case, independence from the homogenising tendency of American-led globalisation that eventually destroys the human.

What Morrison and the numerous Scottish artists and writers collectively create is a sense, not of a narrow Scottishness, but rather of the way Scotland relates to the world. It is in that sense that literature and the arts are so crucial to the political debate because they provide a deeper sense of the implications of the construction of identity, in a period in which some of the debate on the streets of Scotland has been simplified to the question of whether people were British or Scottish or both, or more precisely when it has become locked in what Denise Mina calls "binary, adversarial discussions". Riach asserts that what is at stake is the vital connection that can be drawn between the individual and the world:

Every single poem, song, play, story, novel, gives us a way of looking at the world. It embodies an attitude to experience. [...] This is what literature helps us to do [...] it [...] opens up the world to all of us. (Riach, 70)

One might argue conversely that literature also opens all of us to the world. But in order to do that, it actually needs a place to speak from, a centre with a centre. While it was easy to have the artists comments on the referendum before it took place, in the months that have since elapsed, it has been comparatively more difficult to get an artist's opinion 
about the result ${ }^{27}$. And yet, as many commentators have since argued, the Yes Campaign changed the future of Scotland in a long-lasting way, precisely because of the "vision", the "dream" that the artists and writers brought to it. As Iain MacWhirter put it:

I believe that one of the reasons the Yes campaign generated such momentum since the referendum is because it dealt, not just in fact and statistics, but in vision and emotion - the stuff of literature and theatre. I argue that groups like National Collective not only lent colour and vibrancy to the campaign, they helped communicate the independence message to a wide group of people who are normally resistant to conventional political discourse. (MacWhirter, 27)

Gray, who was asked for a comment by The Scotsman newspaper in the days following the result very briefly replied that it was a sad day for Scotland and that he was going back to work. This paradoxically shows the strength of a phenomenon that started many years before the referendum conversation, and that will continue after the vote. It shows that there are multiple stories still waiting to be told. Caledonia will keep dreaming.

\section{Bibliography}

Bell, E. and Miller G., (eds), Scotland in Theory: Reflections on Culture and Literature, Amsterdam and New York: Rodopi, 2004.

Bell, E., Questioning Scotland: Literature, Nationalism, Postmodernism, Basingstoke and New York: Palgrave Macmillan, 2004

Beveridge C. and Turnbull, R., The Eclipse of Scottish Culture: Inferiorism and the Intellectuals, Edinburgh: Polygon, 1989.

${ }^{27}$ Notwithstanding the fact that the National Collective essay on the referendum result was read by 200,000 and tweeted by 75,000 . 
Bissett, A., Collected Plays 2009-2014, Glasgow: Freight Books, 2015.

Bissett, A., "Vote Britain", http://alanbissett.com/2012/01/13/mycontribution-to-the-debate-on-scottish-independence/ , consulted $20 / 2 / 15$.

Calder, A., Scotlands of the Mind, Edinburgh: Luath Press, 2002.

Carruthers, G., Goldie, D. and Renfrew, A., (eds.), Beyond Scotland : New Contexts for Twentieth-Century Scottish Literature, Amsterdam and New York : Rodopi, 2004.

Edinburgh Review 100, 1999.

Ferguson B., The Scotsman, February 24, 2014. http://www.scotsman.com/what-s-on/theatre-comedy-dance/alanbissett-scottish-independence-play-at-fringe-1-3317276, consulted February 2015

Hames, S., (ed.), Unstated: Writers on Scottish Independence, Edinburgh: Word Power books, 2012.

Klee, P., "Credo du créateur » in Théorie de l'Art moderne, Gonthier, Genève, 1969.

Lambert, M., "The Age of Capitals: Edinburgh as Culture City", in G. Hassan, E. Gibb and L. Howland (eds), Scotland 2020: Hopeful Stories for a Northern Nation, London : Demos.

MacWhirter I., Disunited Kingdom: How Westminster won the referendum but lost Scotland, Glasgow: Cargo Publishing, 2014.

Manfredi, C. (ed.), Alasdair Gray, Ink for Worlds, Basingstoke and New York: Macmillan, 2014.

Moffat, A. and Riach, A., The Arts of Independence: The Cultural Argument and Why it Matters Most, Edinburgh: Luath Press, 2014.

Morrison, E., Tales from the Mall, Glasgow: Cargo, 2012. 
Pittin-Hedon, M.-O., The Space of Fiction: Voices from Scotland in a PostDevolution Age, Glasgow: ASLS, 2015.

Robertson, J., 365: stories, London: Penguin, 2014.

Valéry, P., CEurres, éd. par J. Hytier, vol. I, Paris, Gallimard (coll. de la Pléiade), 1957.

Welsh, I., Trainspotting, London: Mandarin, (1994), 1993. 